\title{
Episodic Volunteering in Sport Events: A Seven-Country Analysis
}

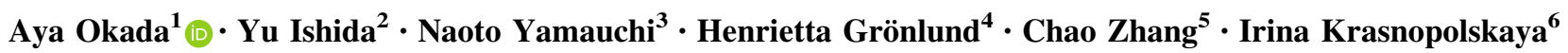

Accepted: 14 October 2021/Published online: 12 November 2021

(c) International Society for Third-Sector Research 2021

\begin{abstract}
Given its ubiquitous nature, sport events are one of the most popular venues for episodic volunteering around the world. This article explores the rare dataset of volunteering in sport events in seven countries-Finland, Ghana, India, Japan, Switzerland, Tanzania, United States-to overview the differences and similarities identified in demography, volunteers' reactions to hosts' management strategies, satisfaction, and intention to volunteer again. Key findings include differences in the level of satisfaction, where responses among American volunteers
\end{abstract}

Aya Okada

aya.okada.e3@tohoku.ac.jp

Yu Ishida

ishiday@myu.ac.jp

Naoto Yamauchi

yamauchi@osipp.osaka-u.ac.jp

Henrietta Grönlund

henrietta.gronlund@helsinki.fi

Chao Zhang

zhangchao5@mail.sysu.edu.cn

Irina Krasnopolskaya

ikrasnopolskaya@hse.ru

1 Graduate School of Information Sciences, Tohoku University, Sendai, Japan

2 School of Project Design, Miyagi University, Miyagi, Japan

3 Osaka School of International Public Policy, Osaka University, Osaka, Japan

4 Faculty of Theology, University of Helsinki, Helsinki, Finland

5 School of Communication and Design, Sun Yat-Sen University, Guangzhou, China

6 Higher School of Economics, National Research University, Moscow, Russia were the highest. We also find that although well-organized management strategies such as quality training, communication, and proper appreciation led to higher satisfaction, these factors did not contribute to volunteers' intent to volunteer again. Such management style might be too impersonal with less autonomy on the part of volunteers that they may not feel needed in future events. Somewhat messy management might motivate volunteers to participate again.

Keywords Episodic volunteering - Event volunteering · Sport · Comparative analysis

\section{Introduction}

From the Olympic Games (White, 2014; Moreno et al., 1999), Universiade (Jiang et al., 2017), a local marathon race (Matsunaga, 2012), to community competitions, sport events of all types and scales have been a common venue for episodic volunteering. ${ }^{1}$ In these events, volunteers provide services to athletes, audiences, and the media, offering support in management and operations. Their contributions vary from coaching, technical support, language skills, medical services, to cleaning up the venue. Volunteer contributions not only allow organizers to save costs, but also to expand the quantity, quality, and diversity of services at these events (Strigas, 2003). In many cases, volunteers bring enthusiasm to the event that helps to enhance visitor satisfaction and community support (Smith

\footnotetext{
${ }^{1}$ In this article, episodic volunteering is defined as “.... one-time (usually a few hours) assignment to perform a non-complicated task that does not require elaborate training or, alternatively, a very specialized and specific task, such as pro bono volunteering utilizing skills already possessed by the volunteer (Cnaan et al., 2021, p. 4)."
} 
et al., 2014a, b). Volunteers are an integral part of sport events in many countries (Cuskelly et al., 2006).

Volunteering in sport events has characteristics that may differentiate it from episodic volunteering at other types of events. First, there is much diversity in scales of sport events. They range from small, local events such as a community event held at a local park to large-scale mega events such as national championships or worldwide professional matches. Such diversity and frequency may offer potential volunteers more opportunities and easier access to fulfill their motivation to contribute to sport events. Second, volunteers are often visible in sport events. Given their proximity to athletes and spectators, volunteers are often recognizable and are more likely to enjoy the excitement and enthusiasms. Third, since many sport events recur over time, some event organizers have ample experience of working with volunteers. These hosts might have well-structured, organized management plans in coordinating volunteers. This is particularly true for largescale mega events that take place regularly. Smaller events may also be structured, but may be managed in a more ad hoc manner.

Even though sport event volunteering has taken place all around the world, there has been limited efforts to bring in a comparative perspective to understand sport event volunteering. Hallmann and Fairly (2019) is one of the few works that looks across multiple countries with a set of rich chapters documenting and characterizing sport event volunteering in 24 countries around the world. Fairley et al. (2013) examines sport event volunteering in Korea, but with keen perspective to compare against frameworks developed in the West. This paper joins these studies to expand our understanding on sport event volunteering globally.

We explore a rich dataset of episodic volunteers in seven countries-Finland, Ghana, India, Japan, Switzerland, Tanzania, United States - to grasp the global trend of volunteering in sport events. We document and examine country-level differences in demography of sport event volunteers, volunteers' actions at the events, and their postevent reflections. We also explore the level of satisfaction among sports volunteers as well as their intention to volunteer again for a similar event in the future, and examine contributing factors.

A rare dataset of countries from multiple continents was made possible by a global project on episodic volunteering where data were collected in nineteen countries. Multiple papers from this project are planned to be published as part of a special issue on episodic volunteering (e.g., Compion et al., 2021), and as such, this paper focuses specifically on volunteering in sport events. An important discussion on the relationship between formal volunteering and episodic volunteering has been published in a separate piece (Cnaan et al., 2021).

In exploring the global phenomenon of sport event volunteering, we shed light on its potential "legacy" of motivating volunteers to participate again in the future. The article first reviews existing knowledge on creating "legacy" in sport event volunteering, focusing on factors that lead to volunteers having intention to participate again. This is followed by a description of the data and methods employed for the study. We then present a descriptive overview of sport event volunteers, highlighting variance observed across the seven countries. We identify notable differences between countries that hosted mega events, presumably with wellstructured and organized management strategies, and countries that hosted smaller events. Also presented will be an analysis of factors that contribute to satisfaction and intention to volunteer again among sport event volunteers. A key argument made is that while hosts' management strategies to offer quality communication, training, and proper appreciation do lead to higher level of satisfaction among sport event volunteers, these approaches do not lead to their willingness to participate again in the future. The article concludes with a discussion of the findings, limitations, and suggestions for future research.

\section{Creating Legacy: Intention to Volunteer Again}

There is a rich set of studies on volunteering in sport, ranging from the level of individual, institutional, multilevel, and policy (Wicker, 2017). Studies focused specifically on sport events have explored multiple perspectives of volunteering, from volunteers' motivations (Fairley et al., 2007; Giannoulakis et al., 2008), hosts' management strategies (Carnicelli-Filho, 2014), to volunteers' assessment of the experience (Jiang et al., 2017).

Whether volunteering at sport events affects one's willingness to volunteer again in the future as "legacy" of sport event volunteering has captured much scholarly interest. Such expectation is often seen among large-scale, mega events (Rogerson et al., 2021). For example, International Olympic Committee (2019) sees volunteers as the "heartbeat" of Olympic legacy and follow-up on whether and how volunteers in the past games have continued their volunteering activities. Second, because sport events also take place in a more local settings in a smaller scale, closely linked to people's everyday lives like community sport clubs (Nagel et al., 2018; Vehmas et al., 2018), the occasion is captured as a suitable venue to motivate people to continue volunteering.

What factors of sport event volunteering contribute to motivating volunteers to participate again in the future? Below we review existing knowledge and draw 
hypotheses, where possible, for examining our dataset of the seven countries.

\section{Hosts' Management Strategies}

Volunteers' reactions to how event organizers managed the logistics have been identified to have a major impact on volunteers' intention to participate again in the future.

Among many aspects of volunteer management, communication between volunteers and hosts is known to motivate volunteers for their future actions. From a study on the 2016 Winter Youth Olympic Games, Sand et al. (2017) identified communication about task specification and providing feedback on volunteers' performance at the event to be the key factors. Pauline (2011) examined event volunteers in the Professional Golf Association (PGA) circuit and found that while the overall level of satisfaction was quite high, volunteers were concerned about the quality of communication as well as recognition received for their work. Showing appreciation for volunteering work is important in keeping up volunteers' motivation.

Assigning appropriate tasks to volunteers is another important factor (Elstad, 1996). Examining volunteers at the 2001 Canada Summer Games, Doherty (2009) found that volunteers who felt overloaded with assigned tasksfeeling pressured to perform well and/or to have been taken advantage of by paid staff or senior volunteers-had less intention to volunteer again for another event.

Provision of training for volunteers' tasks is also identified as a factor contributing to volunteers' willingness to participate in the future (Sand et al., 2017). Training procedures were also identified as a factor leading to volunteer satisfaction, which in turn led to intention for future volunteering in the case of the XXVI Summer Universiade (Jiang et al., 2017). Volunteers at the Rugby World Cup 2011 also found training as one of the highest points in their pre-event experience (Lockstone-Binney, 2014).

Tangible benefits that volunteers receive are also important. From the study on the 1994 Lillehammer Winter Olympic Games, Elstad (1996) found that poor arrangement of transport, food, and accommodation leads to a decrease in satisfaction among volunteers, which in turn motivating volunteers for future participation. Receiving a uniform and accreditation pass was also found to be an exciting moment for volunteers at the Rugby World Cup 2011 (Lockstone-Binney, 2014).

Relationship with the hosts is another important factor that determines future volunteering. From the case of the XXVI Summer Universiade, Jiang et al. (2017) highlighted favorable attitude to the host and host's goals influenced satisfaction and thus to intention to volunteer again. Nichols and Ralston (2014) compared two types of volunteers at the 2010 London Olympics/Paralympic Games:
Game Makers (volunteers at game sites) and Ambassadors (volunteers who supported visitors away from the main venues). The study found that the Ambassadors program, managed by local governments, offered greater potential for encouraging post-event volunteering. Although host organizations that managed Game Makers were disbanded after the event, local governments did have an explicit objective of generating a legacy of increased volunteering from the outset, and were better placed to continue and develop their relationship with the volunteers and hosting them in future local events.

From these studies, we draw the following hypotheses for this study:

H1. Ensuring good communication with volunteers enhances their satisfaction and leads to intention to participate again in the future.

H2. Providing sufficient training to sport event volunteers leads to satisfaction and intention to participate again in the future.

H3. Organized logistics leads to satisfaction and intention to participate again in the future.

H4. Showing appreciation to volunteers, not only in the form of tangible tokens but personal appreciation in any form, is significant in enhancing satisfaction and intent to volunteer again.

\section{Positive Life Experience}

Personal benefits that volunteers perceive in volunteering at sport events are another factor that impact their motivation to participate again in the future.

Being able to interact with others is one of such positive life experiences. Elstad (1996) identified opportunities to network with others, while Jiang et al. (2017) found favorable attitude to other volunteers and teamwork as a factor leading to future volunteering. Meeting people was also among the highest pre-event moments for volunteers at the Rugby World Cup 2011 (Lockstone-Binney, 2014).

Sense of community is another factor leading to future participation. Examining volunteers at the 2001 Canada Summer Games, Doherty (2009) found that volunteers who reported feeling that they had contributed to the community were more willing to volunteer in the future. A sense of being part of the celebratory atmosphere also contributes to future volunteering (Elstad, 1996).

Learning and self-development is also identified as motivating volunteers for event volunteering in the future. Looking at the 2002 Commonwealth Games in the United Kingdom, Downward and Ralston (2006) identified personal development experienced as event volunteers as a consistent predictor of volunteers' intention to do the same for another event and to volunteer in general. In a post- 
event survey $85 \%$ responded that they were willing to be involved in another major sport event, and 69\% said that they were interested in volunteering for major events in general.

From these studies, we draw the following hypotheses for this study:

$H 5$. Interacting with other people at sport events leads to intention to participate again in the future.

H6. Having a sense of community leads to satisfaction and intention to participate again in the future.

\section{Impact of Time}

It is important to note that intentions for future volunteering do not always persist post-event. Dickson et al. (2015) argues that volunteers' intentions weaken as time passes. Based on surveys conducted pre-event and post-event 3 months after Sydney World Masters Games in 2009 showed that while $28 \%$ of the respondents in the pre-event survey expected their experience at the event would increase future volunteering, in the post-event survey only $7.5 \%$ reported to be volunteering more. Majority of respondents said that their volunteering experience at the event had no impact on their future volunteering behaviors. With the after-glow of the event, more episodic volunteers may be motivated to volunteer again in the future, but the momentum seems to fade as time passes by.

Our study builds on these past research on sport event volunteering, particularly studies treating the intention to volunteer again in the future. We expand the scope of extant research with the original dataset of sport event volunteers encompassing multiple countries.

\section{Data and Methods}

Of the nineteen countries included in the global project on episodic volunteering (Cnaan et al., 2021), this article focuses on seven countries: Finland, Ghana, India, Japan, Switzerland, Tanzania, United States. These target countries were selected for two reasons. First, responses from these countries included sport event volunteers. Second, data on key variables including volunteers' actions at respective events as well as post-event reflections were available. Table 1 summarizes the details of data collection in respective countries.

A common questionnaire was first developed for all countries, which was translated to the language of each participating country. Note that the data was collected in many different events, but for others, it was collected in one or two events. Scale of sport events also differed across countries. For example, the venues for data collection were mega events for Finland, Switzerland, and the United States.

The dataset consisted of 2506 responses, of which $40.06 \%$ were sport event volunteers. Among diverse types of events that were investigated in the surveys, sport events had the largest sample size, followed by cultural, arts, and music events, religious events, and fundraising events.

\section{Findings: Variance Across Countries}

We first report a descriptive overview of the dataset in four sections: demography, volunteers' actions at the event, reactions to hosts' management strategies, and volunteers' level of satisfaction as well as intention to volunteer again in a similar event. Where available, we report the findings for sport event volunteers and highlight differences observed in comparison to non-sport event volunteers.

\section{Demography}

Gender Sport event volunteers across the seven countries consisted of $49 \%$ males and $51 \%$ females with two individuals identifying themselves as transgender. Ghana, India, Japan, and Tanzania had more males, while Finland and the United States had more female respondents.

Age Of the seven age groups presented in the questionnaire, about $23 \%$ of sport volunteers were between the ages of 18 and $24.21 \%$ of respondents were between ages 45 and 54. In particular, all respondents from India were younger than 34, while respondents from Japan, Switzerland, and the United States were older, in their $40 \mathrm{~s}$ and $50 \mathrm{~s}$.

Volunteer Experience Over 50\% of the sport events volunteers had not volunteered regularly. When asked about the number of years of experience, $24 \%$ had volunteered less than 5 years and $21 \%$ had volunteered for more than 6 years. Switzerland and the United States had more respondents with greater than 6 years of volunteering experience.

\section{Volunteers' Actions at the Event}

This section examines multiple activities of the sport events volunteers, such as hours spent, participation as individuals or in groups, and volunteer assignments.

Hours Spent About $24 \%$ of volunteers across the seven countries spent less than $5 \mathrm{~h}$ for the event, $35 \%$ around 5-10 h, and $41 \%$ spent more than $10 \mathrm{~h}$ (which could result in more than one day of event volunteering). The number of hours of sport events volunteers were longer than for episodic volunteers in other types of events. Longer hours were devoted by sport event volunteers in the United States 
Table 1 Summary of Collected Data

\begin{tabular}{|c|c|c|c|c|c|}
\hline Country & & $\begin{array}{l}\text { Total } \\
\text { responses }\end{array}$ & $\begin{array}{l}\text { Sport } \\
\text { events }\end{array}$ & $\begin{array}{l}\text { Other } \\
\text { events }\end{array}$ & Details of data collection at sport events \\
\hline \multirow[t]{2}{*}{ Finland } & $N$ & 456 & 91 & 365 & \multirow{2}{*}{$\begin{array}{l}\text { Responses were collected online at Jukola relay, one of the biggest competitions of relay } \\
\text { attracting more than } 15,000 \text { participants }\end{array}$} \\
\hline & $\%$ & 100 & 19.96 & 80.04 & \\
\hline \multirow[t]{2}{*}{ Ghana } & $N$ & 257 & 141 & 116 & \multirow{2}{*}{$\begin{array}{l}\text { Responses were collected either in-person, by telephone, or online from November } 2017 \\
\text { through February 2018. Respondents volunteered at many different sport events which } \\
\text { took place in the cities of Accra, Elmina, and Kumasi }\end{array}$} \\
\hline & $\%$ & 100 & 54.86 & 45.14 & \\
\hline \multirow[t]{2}{*}{ India } & $N$ & 355 & 44 & 311 & \multirow{2}{*}{$\begin{array}{l}\text { Responses were collected online in Mangalore (Southern India) and Greater Noida } \\
\text { (Northern India) from April to October } 2017\end{array}$} \\
\hline & $\%$ & 100 & 12.39 & 87.61 & \\
\hline \multirow[t]{2}{*}{ Japan } & $N$ & 500 & 192 & 308 & \multirow{2}{*}{$\begin{array}{l}\text { Responses were collected online from survey panels across the country in January } 2018 \text {. Of } \\
\text { the } 500 \text { responses, at least } 150 \text { responses were ensured to be from those with experience of } \\
\text { volunteering in sport events including marathon races, competitions, and matches }\end{array}$} \\
\hline & $\%$ & 100 & 38.4 & 61.6 & \\
\hline \multirow[t]{2}{*}{ Switzerland } & $N$ & 244 & 142 & 102 & \multirow{2}{*}{$\begin{array}{l}\text { Responses were collected online through Qualtrics between June and December } 2017 \text { from } \\
\text { volunteers at Weltklasse Zürich (World Class Zurich), an annual, invitation-only, world- } \\
\text { class track and field meeting in Zurich hosted by an association for large events of the } \\
\text { track and field club Zurich }\end{array}$} \\
\hline & $\%$ & 100 & 58.2 & 41.8 & \\
\hline \multirow[t]{2}{*}{ Tanzania } & $N$ & 395 & 150 & 245 & \multirow{2}{*}{$\begin{array}{l}\text { Fieldworkers collected responses in-person at three sport events (football, marathon } \\
\text { running, and bull fighting) during the first } 6 \text { months of } 2017\end{array}$} \\
\hline & $\%$ & 100 & 37.97 & 62.03 & \\
\hline \multirow{2}{*}{$\begin{array}{l}\text { United } \\
\text { States }\end{array}$} & $N$ & 299 & 244 & 55 & \multirow{4}{*}{$\begin{array}{l}\text { Responses collected online (some in articles) from volunteers at the } 2018 \text { Super Bowl } \\
\text { (American football championship game) between November } 2017 \text { to July } 2018\end{array}$} \\
\hline & $\%$ & 100 & 81.61 & 18.39 & \\
\hline \multirow[t]{2}{*}{ Total } & $N$ & 2506 & 1,004 & 1502 & \\
\hline & $\%$ & 100 & 40.06 & 59.94 & \\
\hline
\end{tabular}

( $92 \%$ volunteered for more than $10 \mathrm{~h}$ ), Finland (70\%), and Switzerland $(66 \%)$. As volunteers in these three countries participated in large, mega events, their hours might have been longer. On the contrary, $57 \%$ of volunteers in Japan and $48 \%$ in Ghana volunteered less than five hours.

Participated as Individuals or Groups Sport event volunteers in Finland (64\%), Switzerland (82\%), and the United States $(81 \%)$ tended to volunteer by themselves, while those in India (59\%), Japan (45\%), and Tanzania $(57 \%)$ volunteered as part of an organized group, reflecting the collectivist culture of these societies (Chakravarti, 2018; Ikeji et al., 2018). Some participants in Finland (29\%), Ghana (23\%), Japan (16\%), Switzerland (15\%), and the United States (16\%) volunteered as a group with their friends or relatives.

Assignments Table 2 summarizes the percentage of sport events volunteers who were assigned to eight different tasks. The most popular task across the seven countries were tasks that involved direct contact with beneficiaries which may include athletes and spectators. About $46 \%$ of sport event volunteers were assigned to this task. The figure was slightly higher than for non-sport events. The trend was especially high in Finland with $77 \%$ and Tanzania with $65 \%$.

Also worth noting is that assigned tasks were more diverse for some countries while limited for others. Tasks in Tanzania, for example, did not cover public relations and marketing, online volunteering, fundraising, or supporting professionals and volunteers. India also did not have the tasks on fundraising and supporting professionals and volunteers. The United States and Ghana had the most balanced in terms of variety of assigned tasks. For example, $50 \%$ of sport event volunteers were engaged in virtual volunteering in the United States. Ghana and the United States were the only countries with substantial percentages of volunteers involved in fundraising, 23 and $24 \%$, respectively. In the United States, where sports are more commercialized than other parts of the world, events of professional sports invite many volunteers including those from community groups to raise funds at the venue (Farr \& Green, 2018).

Completion of Assignments In Finland, Ghana, Japan, Switzerland, and the United States, more than $95 \%$ of volunteers completed their assignments as planned. The figures were slightly lower for India $(73 \%)$ and Tanzania $(86 \%)$. The low percentage of India may be explained by the characterization that sport event volunteers prioritize personal relationships with event organizers and other volunteers. Chakravarti (2018) discussed that Indian volunteers are more willing to extend their hours or accept additional tasks when they have such relationships. Personal calls or invitations from event managers are known to lower attrition among volunteers in India. 
Table 2 Assigned tasks among sport event volunteers

\begin{tabular}{|c|c|c|c|c|c|c|c|c|}
\hline & $\begin{array}{l}\text { Finland } \\
(\%)\end{array}$ & $\begin{array}{l}\text { Ghana } \\
(\%)\end{array}$ & $\begin{array}{l}\text { India } \\
(\%)\end{array}$ & $\begin{array}{l}\text { Japan } \\
(\%)\end{array}$ & $\begin{array}{l}\text { Switzerland } \\
(\%)\end{array}$ & $\begin{array}{l}\text { Tanzania } \\
(\%)\end{array}$ & $\begin{array}{l}\text { United States } \\
(\%)\end{array}$ & $\begin{array}{l}\text { Total } \\
(\%)\end{array}$ \\
\hline 1. Volunteer leader & 8 & 23 & 45 & 15 & 18 & 10 & 36 & 20 \\
\hline 2. Preparation preevent & 32 & 25 & 63 & 46 & 29 & 11 & 37 & 33 \\
\hline $\begin{array}{l}\text { 3. Direct contact with } \\
\text { beneficiaries }\end{array}$ & 77 & 30 & 35 & 52 & 31 & 65 & 30 & 46 \\
\hline 4. Postevent cleanup tasks & 11 & 17 & 22 & 32 & 23 & 14 & 12 & 19 \\
\hline 5. Public relations/marketing & 9 & 40 & 28 & 6 & 5 & 0 & 28 & 14 \\
\hline 6. Volunteering virtually & 3 & 19 & 27 & 2 & 5 & 0 & 50 & 13 \\
\hline 7. Fundraising & 1 & 23 & 0 & 3 & 0 & 0 & 24 & 8 \\
\hline $\begin{array}{l}\text { 8. Supporting professionals/ } \\
\text { organizers }\end{array}$ & 11 & 29 & 0 & 19 & 28 & 0 & 18 & 17 \\
\hline
\end{tabular}

\section{Reactions to Hosts' Management Strategies}

Event logistics How did volunteers feel about the organization of the event logistics, such as getting to their assignments and shift time? $46 \%$ felt that the sport event was well organized, a figure higher than for non-sport volunteers at $36 \% .81 \%$ of sport event volunteers in the United States gave this response, followed by Finland (60\%), Switzerland (51\%), and Ghana (50\%). Those in India did not see their sport event as well organized (12\%), nor did sport event volunteers in Tanzania (11\%).

Communication How did volunteers view their communication with the event organizers? $48 \%$ of sport event volunteers rated the quality of communication as high, compared to $34 \%$ of non-sport event volunteers. This figure was particularly high for the United States $(76 \%)$ but low for Japan (25\%) and India (12\%).

Event Team Response Eighty-two percent of sport events volunteers said that the event team responded well to their queries. This figure was slightly lower than for nonsport events (86\%). About $90 \%$ or more sport event volunteers in Finland, Switzerland, Tanzania, and the United States had favorable assessments of event organizers' communication. The figure was slightly lower (78\%) for Japan, a country in which institutionalization of sport event volunteering has been identified as the major challenge (Ikeji et al., 2018). Figures for Ghana and India were lower still at around $50 \%$.

Training Forty-six percent of sport event volunteers across the seven countries rated the training as high, much greater than the same figure for non-sport event volunteers (27\%). The figure was particularly high for the United States $(71 \%)$, followed by Tanzania (53\%). Sport event volunteers in India did not see their trainings as high quality $(14 \%)$.
Appreciation Fifty-six percent of sport event volunteers across the seven countries felt that they were properly appreciated. The figure was higher than that of non-sport event volunteers at $43 \%$. The level was particularly high in the United States (88\%), Finland (76\%), and Switzerland (70\%). Those in India and Japan did not feel as well appreciated compared to other countries under study.

In what forms did volunteers receive their appreciation? Compared to other types of events, volunteers at sport events were more likely to receive tokens of appreciation (bag, hat, t-shirt) for their service. Eighty percent of sport event volunteers received some token, while the same figure was $29 \%$ for other types of events. The figure was particularly high for the United States (100\%), Tanzania (96\%), Finland (87\%), and Switzerland (80\%).

Across the seven countries, $38 \%$ of the respondents received some sort of credentials, a figure higher than for non-sport volunteers, $15 \%$ of whom received credentials. Snacks were given to $84 \%$ of sport event volunteers, which again was higher than for non-sport events $(71 \%)$. The figure reached $100 \%$ for Finland, Tanzania, and the United States, and $91 \%$ for Switzerland. As data for these countries were collected in mega events, volunteer management was more institutionalized than others that provision of credentials was put in place. Japan showed the lowest figure with $42 \%$. Japanese people see volunteering as something without a reward (Ikeji et al., 2018).

Event volunteers may also receive verbal appreciations. $76 \%$ of the respondents across the seven countries received a "thank you" from their supervisors. Although the figure was over $80 \%$ for six countries, it dropped to $19 \%$ for Japan. $75 \%$ of respondents across the seven countries also received a "thank you" from people whom the volunteers had helped. Again, while the figure was over $60 \%$ for six countries, it was much lower in Japan at 34\%. 
A letter expressing "thank you" is another way that sport event volunteers may receive appreciation. $43 \%$ of the respondents received such a letter across the seven countries, which was higher than the $27 \%$ in non-sport events. The figure was only $9 \%$ for Japan, and none in Tanzania.

Perceived Benefits Sport event volunteers saw several benefits in taking on the tasks. First, some felt satisfied working with other people. As shown in Table 3, across the seven countries $55 \%$ responded that they had fully received this benefit. This percentage was higher than for non-sport volunteers at $42 \%$. The United States (86\%) and Finland $(75 \%)$ had larger proportions of sport event volunteers who were satisfied with working with other people. By contrast, the percentage was low for India with $20 \%$, Tanzania with $30 \%$, and Japan with $32 \%$.

Taking pride in being part of the community is another benefit that event volunteers may perceive. 59\% of sport event volunteers expressed that they fully received this benefit, higher than $39 \%$ for non-sport event volunteers. The figures were highest for the United States with $95 \%$ and Finland with $72 \%$. In Finland, a typical sport volunteers are parents active in local sport clubs (Vehmas et al., 2018). As such, it may be easier for Finnish volunteers to feel the sense of community. By contrast, sport event volunteers in India and Japan did not realize this benefit as much, with $21 \%$ and $26 \%$, respectively.

Event volunteers also enjoy meeting new people. $57 \%$ of sport event volunteers said that they fully realized this benefit. The figure was higher than for non-sport event volunteers at $38 \%$. Sport event volunteers enjoyed meeting new people in the United States (90\%), followed by Finland (69\%), Ghana (58\%), and Tanzania (52\%).

Volunteers may feel positive about being able to utilize their skills in volunteer work. Across the seven countries, $45 \%$ of sport event volunteers fully realized this benefit, compared to fewer non-sport event volunteers (34\%). The figure was relatively high for the United States (69\%), Ghana (58\%), Finland (57\%), and Switzerland (55\%) but low for India (21\%), Japan, (21\%), and Tanzania (16\%). As was discussed before, there was much diversity in assignments in the four countries with higher percentage. As volunteers were provided with opportunities to engage in many different types of work, there were more chances of bringing in their expertise.

Volunteers may look for fun and challenge in event volunteering. $49 \%$ of sport event volunteers across the seven countries attained this benefit, higher than for nonsport event volunteers $(26 \%)$. The highest rate was for the United States (85\%), and Japan showed the lowest level $(21 \%)$. This finding echoes the characterization of American volunteers by Farr and Green (2018) that volunteering in sport events is perceived as an option for leisure, and of
Japanese volunteers by Ikeji et al. (2018) that volunteering is considered a self-sacrificing activity without a reward.

\section{Overall Satisfaction and Intention to Volunteer Again}

To what extent were sport event volunteers satisfied with their experience? Table 4 shows that those in the United States and Switzerland expressed higher levels of satisfaction. Volunteers in Finland, Ghana, and Japan were moderately satisfied, whereas in Japan about $25 \%$ and in India $27.3 \%$ reflected that their experience was either "horrible, poor, or fair."

Turning attention to intention to volunteer again for a similar event in the future, as summarized in Table 5, in six out of seven countries over $70 \%$ of the respondents were willing to do so. The percentage was particularly high for Tanzania (99\%), the United States (97\%), and Switzerland $(85 \%)$. By contrast, volunteers in India were reluctant to volunteer again, with $31.8 \%$ giving a clear "no."

\section{Factors that Contribute to Satisfaction and Intent to Volunteer Again}

To better understand country differences as well as factors that may have led to the level of satisfaction and intent to volunteer again for a similar event in the future, we employed the ordered logit model estimation and present the odds ratios. Variables are chosen to test the hypotheses drawn from the existing studies on sport event volunteering in Sect. 2. We include country dummy variables to examine country differences and six variables on volunteers' post-event reflections, each asked in a scale of ten from 1 (strongly disagree) to 10 (strongly agree). Gender, age, number of years of regular volunteering, and number of hours spent to volunteer for the sport event is also included in the models. Descriptive statistics of the variables are presented in Table 6 .

In the two models presented in Table 7, two dependent variables are estimated: (1) overall satisfaction and intent to volunteer again with country differences and (2) overall satisfaction and intent to volunteer again with volunteers' post-event reflections.

Regarding the results of Model 1, we find that the level of satisfaction was the highest in the United States. The odds of fulfilling more overall satisfaction toward sports volunteers are 0.115 times smaller (for India), following 0.197 (Tanzania), 0.202 (Japan), 0.316 (Finland), and 0.405 (Ghana), than the United States, holding all other variables constant. The same trend was observed in Model 2 on intention to volunteer again for a similar event. For a standard deviation increase in "years volunteering regularly" and "number of hours volunteered," the odds of 
Table 3 Perceived benefits among sport event volunteers

\begin{tabular}{|c|c|c|c|c|c|c|c|c|c|}
\hline & Country N & $\begin{array}{l}\text { Finland } \\
(\%)\end{array}$ & $\begin{array}{l}\text { Ghana } \\
(\%)\end{array}$ & $\begin{array}{l}\text { India } \\
(\%)\end{array}$ & $\begin{array}{l}\text { Japan } \\
(\%)\end{array}$ & $\begin{array}{l}\text { Switzerland } \\
(\%)\end{array}$ & $\begin{array}{l}\text { Tanzania } \\
(\%)\end{array}$ & $\begin{array}{l}\text { United } \\
\text { States }(\%)\end{array}$ & $\begin{array}{l}\text { Total } \\
(\%)\end{array}$ \\
\hline \multirow[t]{3}{*}{ Satisfied working with other people } & I do think so & 75 & 57 & 20 & 32 & 54 & 30 & 86 & 55 \\
\hline & $\begin{array}{l}\text { I think so in } \\
\text { a part }\end{array}$ & 23 & 31 & 59 & 41 & 43 & 70 & 12 & 37 \\
\hline & $\begin{array}{l}\text { Do not think } \\
\text { so }\end{array}$ & 2 & 12 & 22 & 27 & 2 & 0 & 1 & 9 \\
\hline \multirow{3}{*}{$\begin{array}{l}\text { Took pride in being part of the } \\
\text { community }\end{array}$} & I do think so & 72 & 57 & 21 & 26 & 57 & 51 & 95 & 59 \\
\hline & $\begin{array}{l}\text { I think so in } \\
\text { a part }\end{array}$ & 26 & 35 & 55 & 42 & 31 & 49 & 3 & 30 \\
\hline & $\begin{array}{l}\text { Do not think } \\
\text { so }\end{array}$ & 2 & 7 & 24 & 32 & 12 & 0 & 1 & 11 \\
\hline \multirow[t]{3}{*}{ Enjoyed meeting new people } & I do think so & 69 & 58 & 21 & 27 & 48 & 52 & 90 & 57 \\
\hline & $\begin{array}{l}\text { I think so in } \\
\text { a part }\end{array}$ & 27 & 34 & 43 & 43 & 42 & 48 & 9 & 33 \\
\hline & $\begin{array}{l}\text { Do not think } \\
\text { so }\end{array}$ & 3 & 7 & 36 & 31 & 9 & 0 & 1 & 11 \\
\hline \multirow[t]{3}{*}{ Able to utilize my skills } & I do think so & 57 & 58 & 21 & 21 & 55 & 16 & 69 & 45 \\
\hline & $\begin{array}{l}\text { I think so in } \\
\text { a part }\end{array}$ & 36 & 32 & 57 & 39 & 36 & 84 & 23 & 41 \\
\hline & $\begin{array}{l}\text { Do not think } \\
\text { so }\end{array}$ & 7 & 10 & 21 & 41 & 9 & 0 & 8 & 14 \\
\hline \multirow{3}{*}{$\begin{array}{l}\text { Looking for something fun and } \\
\text { challenging }\end{array}$} & I do think so & 44 & 50 & 33 & 21 & 41 & 42 & 85 & 49 \\
\hline & $\begin{array}{l}\text { I think so in } \\
\text { a part }\end{array}$ & 48 & 38 & 38 & 42 & 47 & 58 & 12 & 38 \\
\hline & $\begin{array}{l}\text { Do not think } \\
\text { so }\end{array}$ & 8 & 12 & 29 & 38 & 12 & 0 & 3 & 13 \\
\hline \multirow{3}{*}{$\begin{array}{l}\text { The logistics of the event were well } \\
\text { organized }\end{array}$} & I do think so & 60 & 50 & 12 & 22 & 51 & 11 & 81 & 46 \\
\hline & $\begin{array}{l}\text { I think so in } \\
\text { a part }\end{array}$ & 35 & 31 & 55 & 47 & 43 & 89 & 16 & 43 \\
\hline & $\begin{array}{l}\text { Do not think } \\
\text { so }\end{array}$ & 5 & 18 & 33 & 31 & 6 & 0 & 3 & 12 \\
\hline \multirow[t]{3}{*}{ The training for the event was of quality } & I do think so & 45 & 43 & 14 & 23 & 42 & 53 & 71 & 46 \\
\hline & $\begin{array}{l}\text { I think so in } \\
\text { a part }\end{array}$ & 51 & 29 & 52 & 45 & 50 & 47 & 23 & 39 \\
\hline & $\begin{array}{l}\text { Do not think } \\
\text { so }\end{array}$ & 3 & 28 & 33 & 32 & 8 & 0 & 6 & 14 \\
\hline \multirow{3}{*}{$\begin{array}{l}\text { The communication with the organizers } \\
\text { was of high quality }\end{array}$} & I do think so & 52 & 46 & 12 & 25 & 50 & 41 & 76 & 48 \\
\hline & $\begin{array}{l}\text { I think so in } \\
\text { a part }\end{array}$ & 42 & 39 & 54 & 42 & 44 & 59 & 18 & 39 \\
\hline & $\begin{array}{l}\text { Do not think } \\
\text { so }\end{array}$ & 6 & 16 & 34 & 33 & 6 & 0 & 6 & 13 \\
\hline \multirow[t]{3}{*}{ I was properly appreciated } & I do think so & 76 & 53 & 17 & 31 & 70 & 27 & 88 & 56 \\
\hline & $\begin{array}{l}\text { I think so in } \\
\text { a part }\end{array}$ & 20 & 29 & 61 & 38 & 26 & 73 & 9 & 33 \\
\hline & $\begin{array}{l}\text { Do not think } \\
\text { so }\end{array}$ & 5 & 18 & 22 & 32 & 4 & 0 & 3 & 11 \\
\hline
\end{tabular}

more overall satisfaction increase by a factor of 1.112 and 1.448, respectively, holding all other variables constant. However, they were not statistically significant in the model of willingness to volunteer at a similar event.
Model 2 focused on volunteers' post-event reflections. An increase in respondents who agree with "satisfied working with other people," "quality training for the event," "high quality communication with the organizers," 
Table 4 Overall satisfaction among sport event volunteers

\begin{tabular}{lllll}
\hline Country & Horrible, Poor, Fair & Good & Excellent & Total \\
\hline Finland & 5 & 38 & 46 & 89 \\
& 5.6 & 42.7 & 51.7 & 100 \\
Ghana & 12 & 63 & 60 & 135 \\
& 8.9 & 46.7 & 44.4 & 100 \\
India & 12 & 24 & 8 & 44 \\
& 27.3 & 54.6 & 18.2 & 100 \\
Japan & 48 & 75 & 69 & 192 \\
& 25.0 & 39.1 & 35.9 & 100 \\
Switzerland & 0 & 33 & 105 & 138 \\
& 0.0 & 23.9 & 76.1 & 100 \\
Tanzania & 14 & 100 & 34 & 148 \\
& 9.5 & 67.6 & 23.0 & 100 \\
United.States & 1 & 39 & 188 & 228 \\
& 0.4 & 17.1 & 82.5 & 100 \\
Total & 92 & 372 & 510 & 974 \\
& 9.5 & 38.2 & 52.4 & 100 \\
\hline
\end{tabular}

Pearson $\mathrm{chi}^{2}(12)=271.5220 \mathrm{Pr}=0.000$

Table 5 Intent to volunteer again among sport event volunteers

\begin{tabular}{lllll}
\hline Country & No & Not sure & Yes & Total \\
\hline Finland & 1 & 20 & 67 & 88 \\
& 1.14 & 22.73 & 76.14 & 100 \\
Ghana & 12 & 11 & 112 & 135 \\
& 8.89 & 8.15 & 82.96 & 100 \\
India & 14 & 11 & 19 & 44 \\
& 31.82 & 25 & 43.18 & 100 \\
Japan & 9 & 47 & 136 & 192 \\
& 4.69 & 24.48 & 70.83 & 100 \\
Switzerland & 10 & 10 & 120 & 140 \\
& 7.14 & 7.14 & 85.71 & 100 \\
Tanzania & 1 & 0 & 147 & 148 \\
& 0.68 & 0 & 99.32 & 100 \\
United.States & 1 & 5 & 236 & 242 \\
& 0.41 & 2.07 & 97.52 & 100 \\
Total & 48 & 104 & 837 & 989 \\
& 4.85 & 10.52 & 84.63 & 100 \\
\hline
\end{tabular}

Pearson $\operatorname{chi}^{2}(12)=203.3052 \operatorname{Pr}=0.000$

"properly appreciated," the odds of more overall satisfaction increase by a factor of 1.324, 1.181, 1.147, 1.222, respectively. Hypotheses 1, 2, 4, and 5 were supported for satisfaction, while hypotheses 3 and 6 were rejected. On the other hand, in Model 2 on intent to volunteer again indicated that only "satisfied working with other people" was statistically significant. Hypothesis $1,2,4$, and 5 were supported for intention to volunteer again in the future.

In sum, these estimation results show that there are differences among countries (Model 1) and that aspects that contribute to the level of satisfaction and intent to volunteer again are different.

\section{Discussion}

There are two things that stand out in examining the dataset of sports volunteers across the seven countries. First, there seem to be distinct characteristics among sport event volunteers in the United States, Finland, and Switzerland, whose data were collected in large-scale, mega events. For example, there were more diversity in tasks assigned and volunteers felt that they were able to utilize their skills. Volunteers were content with event logistics as well as communication with event organizers, and felt they were properly appreciated. This was a strikingly different trend than Japan or India where volunteers did not see quality communication with the hosts nor provision of sufficient training. Tanzania and Ghana may be positioned somewhere in the middle.

Presumably in mega events, which applied to United States, Finland, and Switzerland in our dataset, volunteer management is more structured and organized compared to smaller events. Tasks are often clearly defined and assigned with detailed directions provided in trainings. A systematic way to communicate with and respond to inquiries from volunteers might be in place. Ways to show appreciation to volunteers may also be more systematic in that distribution of T-shirts or sending out formal thank you letters may be planned. Maas et al. (2021) argue that such program management approach might leave little room for autonomy on the part of volunteers. What to do as volunteers in sport events might be defined tightly that volunteers do not feel they can decide things for themselves or to be creative. On the other hand, smaller, local events tend to have more loose structure in terms of volunteer management. With trainings, communication, and tasks not clearly organized, volunteers might feel frustrated.

The second point that stood out in our findings is that a systematic way of managing volunteers in mega events lead to higher satisfaction, but not towards more willingness to volunteer again in a similar event. From the results of Model 2, we found that quality training for events, quality communication with the organizers, and proper appreciation only contributed to enhancing satisfaction among sport event volunteers, but not to their intent to volunteer again. This relationship between satisfaction and intent to volunteer again is not in line with what previous studies have found that satisfactory experience at an event 
Table 6 Descriptive statistics

\begin{tabular}{llllll}
\hline Variables & Obs & Mean & SD & Min & Max \\
\hline General satisfaction & 974 & 2.429 & 0.659 & 1 & 3 \\
Intentio to volunteer in the similar event & 989 & 2.798 & 0.509 & 1 & 3 \\
Gender: female (d) & 997 & 0.507 & 0.500 & 0 & 1 \\
Age & 997 & 4.238 & 1.714 & 1 & 7 \\
Years volunteering regularly (c) & 997 & 2.654 & 1.881 & 1 & 6 \\
Number of hours volunteered (c) & 997 & 2.175 & 0.787 & 1 & 3 \\
Country: Finland (d) & 997 & 0.090 & 0.287 & 0 & 1 \\
Country: Ghana (d) & 997 & 0.139 & 0.347 & 0 & 1 \\
Country: India (d) & 997 & 0.044 & 0.205 & 0 & 1 \\
Country: Japan (d) & 997 & 0.193 & 0.395 & 0 & 1 \\
Country: Switzerland (d) & 997 & 0.141 & 0.349 & 0 & 1 \\
Country: Tanzania (d) & 997 & 0.148 & 0.356 & 0 & 1 \\
Country: USA (reference) (d) & 997 & 0.244 & 0.430 & 0 & 1 \\
Exp: Satisfied working with other people (c) & 969 & 8.315 & 1.921 & 1 & 10 \\
Exp: Took pride in being part of the community (c) & 965 & 8.373 & 1.979 & 1 & 10 \\
Exp: Organized logistics of the event (c) & 964 & 7.925 & 2.027 & 1 & 10 \\
Exp: Quality training for the event (c) & 940 & 7.784 & 2.187 & 1 & 10 \\
Exp: High quality communication with the organizers (c) & 957 & 7.987 & 2.025 & 1 & 10 \\
Exp: Properly appreciated (c) & 956 & 8.217 & 2.093 & 1 & 10 \\
\hline c) and (d) indicate cal & & & & & \\
\hline
\end{tabular}

(c) and (d) indicate category and dummy variables

would lead to future volunteering (Elstad, 1996) and that management strategies of event hosts are important factors that influence volunteers' intention to participate again in the future (Pauline, 2011).

We interpret this twist in satisfaction and intention to volunteer again in relation to the feeling of being needed among sport event volunteers. Well-structured and organized management style might be too impersonal that volunteers might not feel connected with other people. Indeed, event organizers communicate well, but more in a systematic way, that they do not feel the personal touch. In fact, it has been argued that volunteers' experience at sport events may be attributed more to the informal support offered by their supervisor than formal procedures provided by the organization (Aisbett \& Hoye, 2015).

Taks et al. (2015) argue that in non-mega events that are "generally smaller in size, scale, scope and reach (p. 1)," volunteers face the "potential for tighter social networks and connectedness of the local population with the event, be it as politicians, spectators, volunteers, marketing destination managers, or event organizers (p. 4)." Such interaction with others in the process of running sport events may be what triggers volunteers to feel needed in smaller events. Hosts' management strategies may not be structured, even spontaneous and messy, but that gives volunteers the room for volunteers to interact with others to solve problems or to make decisions together and to be creative.

Indeed, satisfaction in working with others was a statistically significant factor in our analysis for both overall satisfaction of the experience as well as intention to volunteer for a similar event. This finding agrees with prior studies that highlighted such positive life experience is key to both satisfaction (Jiang et al., 2017) and intent to volunteer again (Doherty, 2009). While our study did not find gender differences, Downward et al. (2005) has found that women at a sport event often seek to improve their social capital and become involved in useful networks.

The findings of this study reveal that structured and organized management strategies, as are put in place by hosts of mega events in the United States, Finland, and Switzerland in our dataset, will enhance satisfaction of the volunteer experience in sport events, but will not encourage volunteers to participate again in the future. Volunteers are looking for interaction with others, even in a frustrating and messy management environment, where they feel needed. In thinking about creating a "legacy" of sport events, smaller and more local events may be a more suitable place to pursue this, more so than mega events like the Olympics and the World Cups. 
Table 7 Odds ratio on satisfaction and intent to volunteer again

\begin{tabular}{|c|c|c|c|c|c|c|c|c|}
\hline \multirow[t]{3}{*}{ Ordered Logit Model } & \multicolumn{4}{|c|}{ Model 1: Country Differences } & \multicolumn{4}{|c|}{$\begin{array}{l}\text { Model 2: Volunteers' Post-Event } \\
\text { Reflections }\end{array}$} \\
\hline & \multicolumn{2}{|c|}{ Overall satisfaction } & \multicolumn{2}{|c|}{$\begin{array}{l}\text { Intent to volunteer } \\
\text { again }\end{array}$} & \multicolumn{2}{|c|}{ Overall satisfaction } & \multicolumn{2}{|c|}{$\begin{array}{l}\text { Intent to volunteer } \\
\text { again }\end{array}$} \\
\hline & Odds Ratio & SE & Odds Ratio & SE & Odds Ratio & SE & Odds Ratio & SE \\
\hline Gender: female (d) & 1.243 & 0.205 & 1.350 & 0.307 & 1.263 & 0.224 & 1.296 & 0.337 \\
\hline Age & 1.012 & 0.066 & 0.953 & 0.077 & 0.951 & 0.068 & 0.939 & 0.094 \\
\hline Years of volunteering regularly (c) & $1.112 *$ & 0.061 & 1.043 & 0.066 & 1.074 & 0.068 & 1.028 & 0.067 \\
\hline Number of hours volunteered (c) & $1.448 * * *$ & 0.190 & 1.243 & 0.191 & $1.282 *$ & 0.192 & 1.102 & 0.182 \\
\hline Country: Finland (d) & $0.316 * * *$ & 0.090 & $0.106 * * *$ & 0.050 & $0.351 * * *$ & 0.110 & $0.092 * * *$ & 0.049 \\
\hline Country: Ghana (d) & $0.405 * * *$ & 0.141 & $0.186 * * *$ & 0.102 & 0.744 & 0.310 & $0.176^{* * *}$ & 0.112 \\
\hline Country: India (d) & $0.115 * * *$ & 0.053 & $0.026 * * *$ & 0.017 & 0.425 & 0.229 & $0.040 * * *$ & 0.030 \\
\hline Country: Japan (d) & $0.202 * * *$ & 0.067 & $0.115 * * *$ & 0.059 & 0.588 & 0.240 & $0.169 * * *$ & 0.098 \\
\hline Country: Switzerland (d) & 0.887 & 0.243 & $0.176^{* * *}$ & 0.087 & 1.431 & 0.454 & $0.163 * * *$ & 0.090 \\
\hline Country: Tanzania (d) & $0.197 * * *$ & 0.069 & 5.327 & 6.295 & $0.212 * * *$ & 0.089 & 4.666 & 5.808 \\
\hline \multicolumn{9}{|l|}{ Country: USA (reference) (d) } \\
\hline Exp: Satisfied working with other people (c) & & & & & $1.324 * * *$ & 0.106 & $1.219 * *$ & 0.106 \\
\hline Exp: Took pride in being part of the community (c) & & & & & 1.086 & 0.077 & 1.014 & 0.081 \\
\hline Exp: Organized logistics of the event (c) & & & & & 0.945 & 0.066 & 1.054 & 0.113 \\
\hline Exp: Quality training for the event (c) & & & & & $1.181 * * *$ & 0.065 & 0.884 & 0.092 \\
\hline Exp: High quality communication with the organizers & s (c) & & & & $1.147 * *$ & 0.076 & 1.192 & 0.132 \\
\hline Exp: Properly appreciated (c) & & & & & $1.222 * * *$ & 0.084 & 1.018 & 0.088 \\
\hline /cut1 & -2.357 & 0.552 & -4.291 & 0.812 & 3.432 & 0.918 & -2.142 & 0.995 \\
\hline /cut2 & 0.203 & 0.557 & -2.862 & 0.813 & 6.694 & 0.997 & -0.568 & 1.005 \\
\hline $\mathrm{N}$ & 974 & & 989 & & 904 & & 918 & \\
\hline Log pseudolikelihood & -776.16 & & -438.74 & & -597.41 & & -381.21 & \\
\hline Wald chi $^{2}$ & $223.32 * * *$ & & $84.23 * * *$ & & $262.6 * * *$ & & $104.21 * * *$ & \\
\hline Pseudo $\mathrm{R}^{2}$ & 0.14 & & 0.15 & & 0.28 & & 0.20 & \\
\hline
\end{tabular}

$* * *, * *, *$ indicate statistically significant in $1 \%, 5 \%$, and $10 \%$ level, respectively

(c) and (d) indicate category and dummy variables

\section{Limitations and Future Agenda}

Our study must be understood with caveats. Although our inquiry is novel in incorporating samples from seven countries, respondents self-selected into participation in the study. Second, while we formulated the questionnaire in English with diverse items, for purposes of our cross-national project we had to translate it into multiple languages. Inevitably, issues of translation can arise given a full sample comprising nineteen countries. The countries represented in our study are those in which sport event volunteering occurred.

Readers must also keep in mind that these surveys were administered before the COVID-19 pandemic in 2020. As much as the coronavirus has changed our lives in a multitude of ways, it has also changed how sport events are organized, and how people might contribute to events as volunteers (Ludvigsen \& Hayton, 2020). Doing more things online is likely to become an important part of sport events volunteering in the future. The responses to the questionnaire in our study already showed indications of online volunteering. Across the seven countries examined in this article, $13 \%$ of the respondents were engaged in online activities. The trend was particularly strong in the United States, where 50\% participated online, and in India with $27 \%$. Pre-event trainings were also provided online: $22 \%$ of sport event volunteers across the seven countries received training online. The figure was particularly high for Finland and the United States, $48 \%$ for both countries.

How the pandemic changes the landscape of sport event volunteering is an important question for future research. How are organizers of sport events changing-or not 
changing - their strategies in recruiting and training volunteers? Does the new landscape open-or limit-opportunities for sport event volunteering? If interacting with other people is more important than systematic volunteer management that involves quality communication, training, or proper appreciation in encouraging volunteers to participate again, how can hosts create and realize such environment online? These questions are worth asking in studying sport event volunteering, not only in a single country context, but also across national borders to sustain sport event volunteering.

Acknowledgements We are grateful to Ram Cnaan (University of Pennsylvania) and Lucas Meijs (Erasmus University) for leading the global project of episodic volunteering. Our appreciation also goes to the entire team who collected valuable data in respective countries and provided insights in the process of developing this paper. We also thank the two anonymous reviewers for their comments on the earlier draft.

Funding The authors did not receive support from any organization for the submitted work.

\section{Declarations}

Conflict of interest The authors have no relevant financial or nonfinancial interests to disclose.

Ethical approval and Informed consent This study received the approval of the Institutional Review Board of the University of Pennsylvania. Research participation was informed, voluntary and consensual.

\section{References}

Aisbett, L., \& Hoye, R. (2015). Human resource management practices to support sport event volunteers. Asia Pacific Journal of Human Resources, 53(3), 351-369.

Carnicelli-Filho, S. (2014). Emotions and the Olympic games: the emotional management of volunteers. In Smith, K.A., Lockstone-Binney, L., Holmes, K., and Baum, T. (eds.). Event Volunteering: International Perspectives on the Event Volunteering Perspectives. Abingdon, Oxon: Routledge.

Chakravarti, P. (2018). India. In Hallmann, K. and Fairley S. (eds.). Sports Volunteers Around the Globe: Meaning and Understanding of Volunteering and its Societal Impact. Cham: Springer Nature Switzerland.

Cnaan, R.A., Meijs, L., Brudney, J.L., Hersberger-Langloh, S., Okada, A., \& Rumman, S.A. (2021). You thought that this would be easy? Seeking an understanding of episodic volunteering. Voluntas. Online First.

Compion, S., Cnann, R.A., Brudney, J.L., Jeong, B.G., Zhang, C., \& Haski-Leventhal, D. (2021). 'Young, fun, and free': Episodic volunteers in Ghana, South Africa and Tanzania. Voluntas.

Cuskelly, G., Hoye, R., \& Auld, C. (2006). Working with Volunteers in Sport: Theory and Practice. Routledge.

Dickson, T. J., Darcy, S., Edwards, D., \& Terwiel, F. A. (2015). Sport mega-event volunteers' motivations and postevent intention to volunteer: The Sydney world masters games, 2009. Event Management, 19, 227-245.
Doherty, A. (2009). The volunteer legacy of a major sport event. Journal of Policy Research in Tourism, Leisure and Events, 1(3), 185-207.

Downward, P., Lumsdon, L., \& Ralston, R. (2005). Gender differences in sports event volunteering: insights from Crew 2002 at the XVII Commonwealth Games. Managing Leisure, 10, 219-236.

Downward, P., \& Ralston, R. (2006). The sport development potential of sport event volunteering: Insights from the XVII Manchester Commonwealth games. European Sport Management Quarterly, 6, 333-351.

Elstad, B. (1996). Volunteer perception of learning and satisfaction in a mega-event: The case of the XVII Olympic winter games in Lillehammer. Festival Management \& Event Tourism, 4, 75-83.

Fairley, S., Lee, Y., Green, C., \& Kim, M. L. (2013). Considering cultural influences in volunteer satisfaction and commitment. Event Management, 17, 337-348.

Fairley, S., Kellett, P., \& Green, C. (2007). Volunteering abroad: Motives for travel to volunteer at the Athens Olympic games. Journal of Sport Management, 21(1), 41-57.

Farr, J.R. \& Green, B.C. (2018). United States. In Hallmann, K. and Fairley S. (eds.). Sports Volunteers Around the Globe: Meaning and Understanding of Volunteering and its Societal Impact. Cham: Springer Nature Switzerland.

Giannoulakis, C., Wang, C. H., \& Gray, D. (2008). Measuring volunteer motivation in mega-sporting events. Event Management, 11, 191-200.

Hallmann, K., \& Fairley, S. (2019). Sports Volunteers Around the Globe: Meaning and Understanding of Volunteering and its Societal Impact. Cham: Springer Nature Switzerland.

Ikeji, T., Ito, E., Fairley, S., \& Yamaguchi, S. (2018). Japan. In Hallmann, K. and Fairley S. (eds.). Sports Volunteers Around the Globe: Meaning and Understanding of Volunteering and its Societal Impact. Cham: Springer Nature Switzerland.

International Olympic Committee (IOC). (2019). Volunteers: the "heartbeat" of Olympic legacy. Last accessed August 4, 2021 at https://olympics.com/ioc/news/volunteers-the-heartbeat-of-olym pic-legacy

Jiang, K., Potwarka, L. R., \& Xiao, H. (2017). Predicting intention to volunteer for mega-sport events in China: The case of Universiade event volunteers. Event Management, 21(6), 713-728.

Lockstone-Binney, L. (2014). Volunteering experiences in the buildup to the Rugby World Cup 2011. In Smith, K.A., LockstoneBinney, L., Holmes, K., and Baum, T. (eds.). Event Volunteering: International Perspectives on the Event Volunteering Perspectives. Abingdon, Oxon: Routledge.

Ludvigsen, J. A. L., \& Hayton, J. W. (2020). Toward COVID-19 secure events: Considerations for organizing the safe resumption of major sporting events. Published Online First.

Maas, S. A., Meijs, L. C. P. M., \& Brudney, J. L. (2021). Designing "National day of service" projects to promote volunteer job satisfaction. Nonprofit and Voluntary Sector Quarterly, 50(4), 866-888.

Matsunaga, K. (2012). Motivation of volunteers in the Kyoto marathon 2012: A comparison between voluntary and nonvoluntary participation (in Japanese). The Journal of Business Studies, Ryukoku University, 52(2/3), 55-63.

Moreno, A.B., de Moragas, M., \& Paniagua, R. (1999). The Evolution of Volunteers at the Olympic Games. Paper presented at Symposium "Volunteers, Global Society and the Olympic Movement." Retrieved May 24th, 2017 from http://olympicstu dies.uab.es/volunteers/moreno.html\#one

Nagel, S., Lamprecht, M., Schlesinger, T., Burgi, R., \& Stamm, H. (2018). Switzerland. In Hallmann, K. and Fairley S. (eds.). Sports Volunteers Around the Globe: Meaning and 
Understanding of Volunteering and its Societal Impact. Cham: Springer Nature Switzerland.

Nichols, G. \& Ralston, R. (2014). The 2012 ambassadors: secondclass Olympic volunteers, or the best potential for developing a volunteer legacy from the games? In Smith, K.A., LockstoneBinney, L., Holmes, K., and Baum, T. (eds.). Event Volunteering: International Perspectives on the Event Volunteering Perspectives. Abingdon, Oxon: Routledge.

Pauline, G. (2011). Volunteer satisfaction and intent to remain: An analysis of contributing factors among professional golf event volunteers. International Journal of Event Management Research, 6(1), 10-32.

Rogerson, R., Reid, F., \& Nicholson, R. (2021). Creating an event volunteering legacy: the 2014 Host City Volunteer initiative. Event Management, Online First.

Sand, T.S., Strittmatter, A.M., \& Hadstand, D.V. (2017). 2016 Winter Youth Olympic Games: planning for a volunteer legacy. International Journal of Sport Management and Marketing, 17(4/5/6), 242-260.

Smith, K. A., Baum, T., Holmes, K., \& Lockstone-Binney, L. (2014a). Introduction to event volunteering. In Smith, K.A., Lockstone-Binney, L., Holmes, K., and Baum, T. (eds.). Event Volunteering: International Perspectives on the Event Volunteering Perspectives. Abingdon, Oxon: Routledge.

Smith, K. A., Wolf, N., \& Locksone-Binney, L. (2014b). Volunteer experiences in the build-up to the Rugby World Cup 2011. In
Smith, K.A., Lockstone-Binney, L., Holmes, K., and Baum, T. (eds.). Event Volunteering: International Perspectives on the Event Volunteering Perspectives. Abingdon, Oxon: Routledge.

Strigas, A.D. (2003). Motivational factors for student volunteers and the development of an incentive typology in sports settings. Research Quarterly for Exercise and Sport, 74(Suppl.), 90.

Taks, M., Chalip, L., \& Green, B. C. (2015). Impacts and strategic outcomes from non-mega sport events for local communities. European Sport Management Quarterly, 15(1), 1-6.

Vehmas, H., Koski, P., \& Lehtonen, K. (2018). Finland. In Hallmann, K. and Fairley S. (eds.). Sports Volunteers Around the Globe: Meaning and Understanding of Volunteering and its Societal Impact. Cham: Springer Nature Switzerland.

White. L. (2014). Volunteering for an audience of billions: fifteen minutes of fame at an Olympic games opening ceremony. In Smith, K.A., Lockstone-Binney, L., Holmes, K., and Baum, T. (eds.). Event Volunteering: International Perspectives on the Event Volunteering Perspectives. Abingdon, Oxon: Routledge.

Wicker, P. (2017). Volunteerism and volunteer management in sport. Sport Management Review, 20(4), 325-337.

Publisher's Note Springer Nature remains neutral with regard to jurisdictional claims in published maps and institutional affiliations. 